\title{
The Economic Lock-In in the Current Context and How the Pandemic Covid-19 Influenced the Politics and Legislation
}

\author{
Alexandra - Andreea BRATU ${ }^{\star}$, Ruxandra - Elena BRATU ${ }^{\star \star}$
}

\begin{tabular}{l}
\hline \multicolumn{1}{c}{ A R T I C L E I N F O } \\
\hline Article history: \\
Accepted April 2021 \\
Available online April 2021 \\
\hline JEL Classification \\
F31, 023, D20 \\
Keywords: \\
Economic crisis, Foreign Exchange, \\
Sanitary crisis, Gross domestic \\
product, Unemployed
\end{tabular}

A B S T R A C T

This paper is a resume of an ample research about the impact of Covid-19 on the business, what was the response to the crisis, what were the tax measures, how did the management worked during the crisis. The reason why I choose this theme follows the current context in the economic field. Covid-19 has had a major impact in Romania, the most affected sector was Horeca, because they were closed through out the pandemic. In the first part I wrote about the risks in the economic field and about the measures taken by the government. In the second part I wrote about how the banks helped the affected companies.

(C) 2021 EAI. All rights reserved.

\section{Introduction}

It all started on 26 of February where the first case of COVID-19 was registered in Romania, looking at the official numbers of how quickly the virus is spreading, shown to us though mass media a huge change affecting every day life stile for the people of Romania followed very soon.

March began with very big changes such as the suspension of courses in Romanian education meaning that no student will be able to attend school for an unknown period of time, the decree of the state of emergency which in turn came with its own series of restrictions: hole country was in lock down with no access to transport within or outside the county, local shops restaurants as well as facilities businesses were shut. As a result of the new pandemic rules, the most affected sector was Horeca, especially the restaurants with interior facilities were shut for what had to be a period of nearly 9 months. This is not the only economic sector was hugely affected as nearly $70 \%$ of all companies did not have a risk assessment for such a situation.

Many of the companies resorted to limiting their employee numbers, reducing salaries or shutting down, while other companies tried to continue to operate somewhat normally following the new pandemic rules, but given this people where still hoping and waiting for better solutions coming from the institutions of the Romanian state (Minculete Gh, Olar P, 2016).

\section{Literature review}

Yanis Varoufakis, a professor of Economic Theory at the University of Athens, founder of the DiE25 and former finance minister of Greece said "The Coronavirus is going to accelerate the post 2008 Crisis".

Studying Yanis Varoufakis's article, I noted that the financial crisis of 2008 was never completely overcome, and the double sanitary and financial crisis of 2020 served entirely towards the deepening of the previous crisis. The balance before the 2008 crisis has not been regained over time, a continuous support of normality has been tried, but the equilibrium point has not been reached. Normality was supported by the Central Bank and the Government of the country for sure, but it did not represent a return to the period before the crisis of 2008. (see Yanis, 2020)

With the onset of the new crisis, that of coronovirus, the deficient condition has also increased. Given that debts existed, and people reached the point where they were losing their jobs or their incomes were halved, this aspect has resized the degree of indebtedness by postponing the payment of debts, which has led to a deferred interest, in directly mode at a rising debt for each one (Minculete Gh., Chisega-Negrilă M.A., 2014). The commercial companies, especially those in the field of Horeca, are in the same situation, because their field of activity has been blocked for a period of time, which was enough to trigger a deficit in the whole field. 
Studying the political instruments, I noticed that the state plan pursued at a well-intentioned relaunch, and the degree of influence of the state provided a necessary impetus, cannot be defined as sufficient for the current economic situation, but by the proposed measures supported the much necessary availability for companies in difficulty. For some societies it was a long-awaited recovery, for others it represented a simple state of equilibrium, meant to maintain for a period the society in question at an acceptable level (Minculete Gh, 2013).

\subsection{Decisions, laws, taxation and their influence on the economy}

The Romanian State has come up with a series of measures, similar to those of the Member States of the European Union, among these measures we find:

- Micro-enterprises have been subsidized for the advance payment of corporation tax or income tax;

- The possibility of postponing the payment of VAT in customs for those importers of medicines and equipment necessary for the protection of Covid-19;

- Extension from March 31 to June 30 of the deadline which includes the tax on buildings, land, etc., as well as the bonus granted in the event of an advance payment;

- During the period in which OUG 29/21.03.2020 was in force, no interest and penalties for delay of fiscal obligations were calculated;

- The possibility of settlement from the state budget of technical unemployment indemnities, within the limit of $75 \%$ of the average gross salary, valid for employers who have partially or totally interrupted the activity during the state of emergency;

- Granting days off to parents, with an allowance of $75 \%$ of the gross monthly salary;

- Aid to SMEs in postponing payments for utility services, rent payments, telephone services, as well as state guarantees regarding loans.

Thus, we can see that the Romanian State, like other European states, has provided support to companies in difficulty, both through sums of money and through other measures, such as the deferral of taxes, the non-collection of penalties, etc., with main aim being to minimize the economic crisis.

A valuable aid came from the BNR, through collaboration with the Romanian Government. The purpose of this collaboration was to avoid potential conflicts between the fiscal measures adopted and those of the Central Bank. As we well know, the general economic stability depends directly on the exchange rate, so BNR has prevented the major depreciation of the national currency, keeping the exchange rate relatively stable (see BNR interest rate, 2020).

The decisions and laws adopted by the Government during this period have directly impacted the economy and population of this country. They represented a real and necessary aid for certain companies, but at the same time they triggered a deficit in the state budget.

\subsection{Exchange rate evolution}

In the first quarter of 2020, the leu/euro exchange rate fluctuated, recording successive decreases and increases. In the second quarter of 2020, the leu/euro exchange rate increased (see Exchange rate, 2020).

While the leu/dollar exchange rate decreased successively over the first quarter and continued to decline in the second quarter.

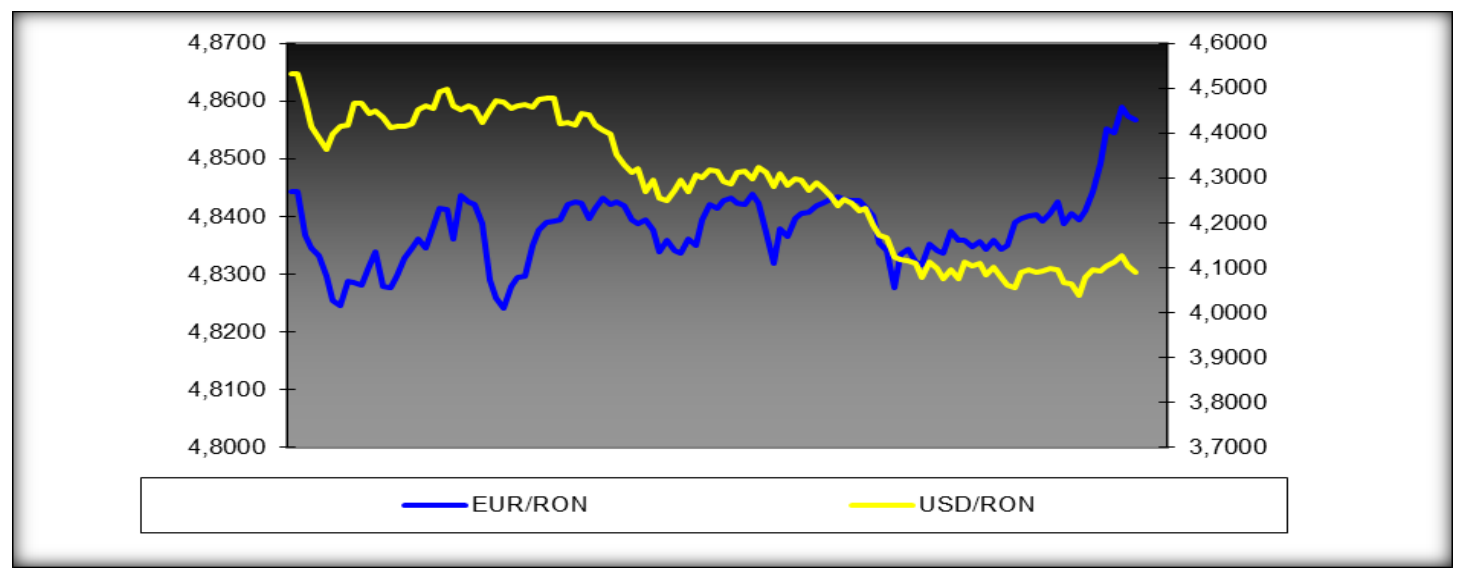

Figure 1. Graphical representation of the exchange rate evolution Source: https://www.cursbnr.ro/

With the Coronavirus pandemic, the economy has stopped worldwide, and the exchange rate fluctuated greatly. At national level, the situation was managed by BNR, for this reason it can be observed that in the last 6 months of this year, exchange rate fluctuations were relatively small. 
September 2020 was a month of highs for the euro exchange rate. The maximum value recorded for one euro is 4, 8750 lei. The leu is falling behind the main currencies, namely the euro, dollar and pound sterling.

\subsection{Ways of preserving and developing wellness with the help of political tools}

The funding came from the state, which offers grants for different sectors of activity. The state plan contains schemes to support agriculture, the agri-food industry, the sanitary industry, the pharmaceutical industry, the transport industry, etc. The plan aims to support their relaunch.

A first grant of support is the Microgrant amounting to 2,000 euros, allocated to expenses for suppliers, utilities and rent. This aid is estimated to have 50,000 companies in various fields, with a budget of 100 million euros. The second refers to grants for working capital, the financed value can reach up to 150,000 euros and is directly addressed to small and medium-sized enterprises that have been affected by the new virus, the final plan being to restart the activity. The third grant offered is the investment grant, the financed value is 50,000 euros and can reach up to 200,000 euros and is addressed to investments aimed at expanding, rehabilitating and modernizing existing units, thus increasing capacity.

But if the company, during the Covid-19 epidemic, worked, not at a full capacity, but choosing not to apply for an emergency certificate, many of these support schemes are not accessible to it.

\subsection{The economy before and after the pandemic and the degree of state influence on it}

In 2020 we are experiencing a double crisis, the health and economic crisis. As far as we could see in recent months, we were not prepared for such a crisis, which hit us hard and had repercussions in Romania on all fronts.

In the first part, panic and hysteria among people caused an explosion of consumption, with people purchasing consumer goods far beyond a person's needs, which led to an increase in sales. And as a parenthesis to this observation, it would be preferable for people to understand that although the price is in most cases higher, buying Romanian goods and products, we help ourselves and the economy of this country.

The economic crisis has primarily affected the Horeca sector and the tourism industry, these being the first sectors to request state support. In the current context, the crisis could determine an increase in tourism on Romanian territory.

The economic crisis has also come with substantial changes in terms of technical unemployment and work from home. For some enterprises, it was a gain and for others a loss. For example, large retail companies have noticed that working from home has increased their work productivity among employees, which has led them to reassess their approach. At the same time, other companies have chosen to send their employees into technical unemployment, thus reducing their salary expenses (see Jobs and economy, 2020).

People's habits have also been drastically influenced, and a first example of this would be the trade that has moved to the online environment, so that the big retail companies that operated in the online environment have experienced an increase in sales and so we can see that there have been companies that have been impacted in a positive way. While local producers have been negatively impacted, some of them have become aware of how people have changed their habit and have also moved their online business.

Another change we all felt was the fall in fuel prices, due to the evolution among international markets, which triggered the collapse in the price of oil.

\subsection{Evolution of gross domestic product}

In the current context, the imbalances in the economy have been amplified due to the increase in the demand for supply of food and household goods and the increase in liquidity needs, which has directly influenced the unfavorable evolution (see PIB Evolution, 2020).

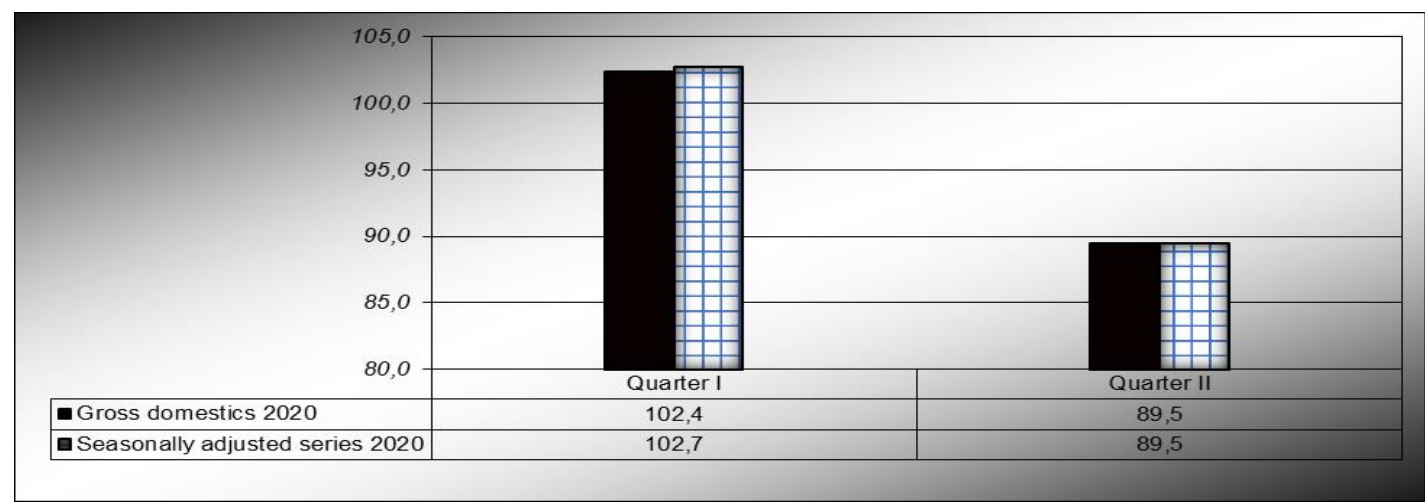

Figure 2. Graphical representation of the evolution of the gross domestic product in 2020 Source: National Institute of Statistics - PIB Evolution 2020 
According to the data released by the National Statistical Institute, comparing the first quarter with the second quarter of 2020, we notice that the gross domestic product in the second quarter registered a decrease of $12.3 \%$. Uncertainty exists because following the evolution of the coronavirus epidemic there is a high probability that gross domestic product will not recover in the next two years.

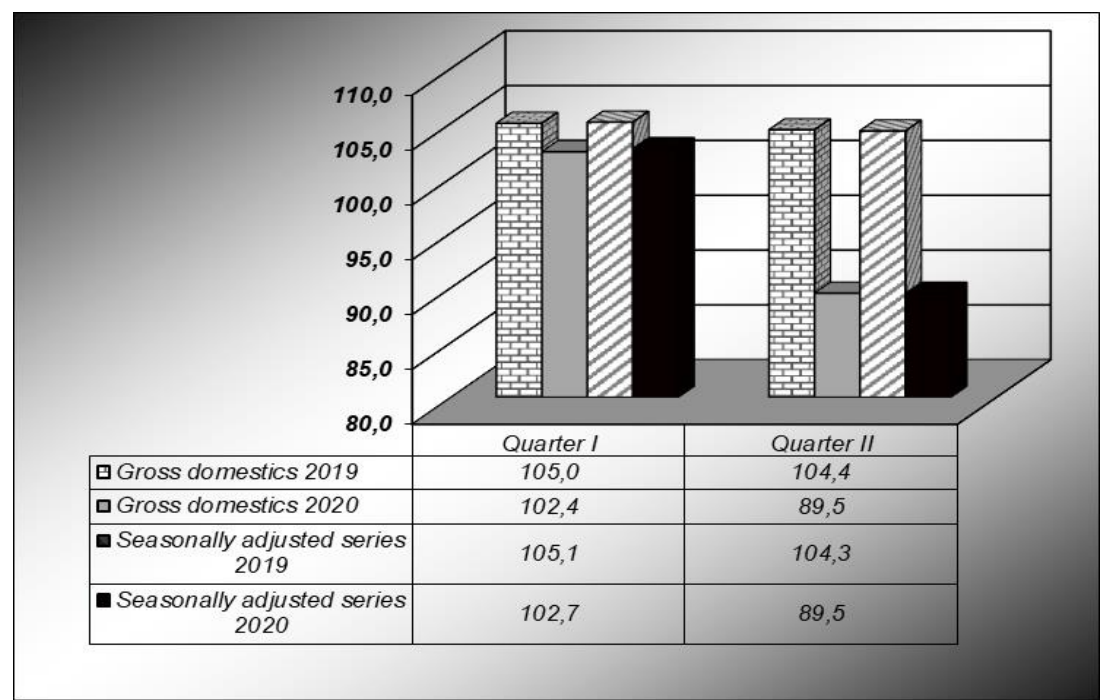

Figure 3. Graphical representation of the evolution of the gross domestic product in the years 2019-2020

Source: National Institute of Statistics - PIB Evolution 2019-2020

Comparing the first quarter of 2019 with the first quarter of 2020, we observe a decrease of $4.7 \%$ on the gross series and a decrease of $3.9 \%$ on the seasonally adjusted series. Also in the second quarter there was a decrease with $10.5 \%$ on the gross series as well as the seasonally adjusted one.

\subsection{Socio-economic and political phenomena}

From a social point of view, Romania presented itself with some advantages, because the majority of employees work in the budgetary system, not as affected as the private one in terms of redundancies or reduction of salaries, so that a public servant received $75 \%$ of salary, while a private sector employee has either suffered a reduction in salary to 50-60\% depending on the company the employee has either been fired or sent to technical unemployment. At the same time, the pensioners, the unemployed persons and the social workers continuing to received the related amounts from the state.

Thus we can conclude that the most affected sector was the private one, although it was in the form of different trends. For example, the Horeca sector represented a collapse, while the IT section continued its activity in the form of "telework" in most companies, which led to a substantial advantage.

Another sector that worked was the courier sector, which during the state of emergency reached high levels due to the change in population's habits. In April of this year, the biggest decrease was recorded, followed in May by a gradual rebalancing, which led to a recovery in June when most companies reopened their activity partially or totally, depending on the field of activity.

The real estate sector chose to continue its projects during the Coronavirus pandemic, so that between March and April it reached a positive threshold, followed by a slight decrease between May and June.

The Romanian economy depends directly on the UE, because with the restart of the extern economy, the demands for Romanian services and products returne with Romania being a country dependent on external demand. With the resumption of production, the Romanian exporters will pay the taxes to the state budget, following that the employees of the private sector gradually regain their purchasing power, the employees of the budget sector can say that they will remain constant, because their revenues have not been affected in an extreme way as was the case in the private sector in certain areas. (Council, 2020)

As Romania is not a country with a strong economy or with a high-performance and developed technical system, it will have a gradual and slow economic recovery that will depend decisively on the great forces of the UE and how they will recover their economy. Another substantial aid will come from corporations, which are owned by foreign investors.

Another strength in Romania's support is the funds allocated by the UE, which are a real aid, used in an efficient and fair way, they should make a large recovery in the current situation. 


\subsection{How the affected sectors managed to comply with the credit agreements and how they were able to access new financing}

In the context of this epidemic, which triggered the lack of liquidity among small and medium-sized enterprises, and among individuals the decrease of incomes, the State of Romania instituted Emergency Ordinance No. 37/2020 on the granting of facilities regarding bank loans. By this Ordinance, both banking and non-banking institutions allow lenders to defer the payment of loans to any natural person affected by the Covid-19 pandemic, without applying the existing conditions in the Regulation of the National Bank of Romania no. 17/2012 regarding credit conditions. But this deferral of the payment of loans also comes with a capitalized interest, so that at the end of the deferral period, interest will be paid.

Delaying the payment of rates is not seen as a difficulty of the debtor in the relationship with the bank, as there are no negative repercussions in the future, generally aspect valid for both individuals and legal persons, which is a strong point.

If regarding the situation of the existing debtors the solution came through an Emergency Ordinance, which made possible the postponement of the credits. Regarding the contracting of a loan, the conditions have become visibly difficult, so some banking institutions have taken measures to this effect, increasing the advance from $15 \%$ to $35 \%$. These changes were due to the health crisis, because technical unemployment and the delay of credit payments triggered a lack of liquidity among the banks, wanting to balance the balance, they increased the advance. This fact for the person in question did not represent an optimistic option, on the contrary in some cases, the credit contracting was waived.

During this epidemic period, certain banking institutions came to the final consumer with different financing proposals, by contracting the respective financial solution, the company of the beneficiary of liquidity, very necessary at the moment, and the banking institution in question, concluded a new credit agreement. Thus the final transaction was fair to both parties involved in the process.

\section{Comparative study before and after Covid-19}

In the next part of the paper we will see how the trade in goods in Romania was positioned in 2020 with the outbreak of Coronavirus, compared to 2019 when it does not exist in our country and how big was the impact in terms of value on imports and exports.

\subsection{Trade in goods in Romania}

In Figure 4 we can see that in January 2020 there was an increase in both imports and exports, compared to January 2019 (Insse, 2020).

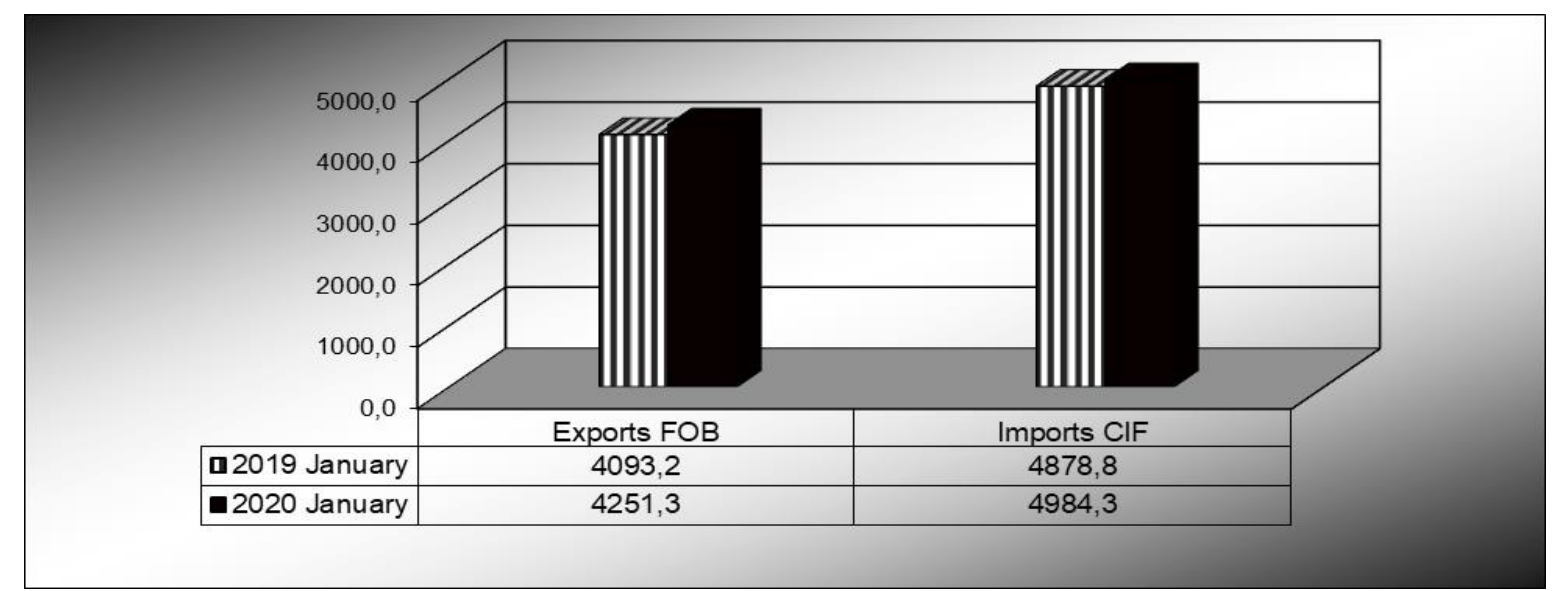

Figure 4. Comparative graphical representation January 2019-2020 (expressed in millions of euros) Source: National Institute of Statistics - International Trade in Goods of Romania

The Coronavirus epidemic had not yet occurred in Romania at that time, which meant that things were unfolding in their usual way according to the first month of a calendar year. 


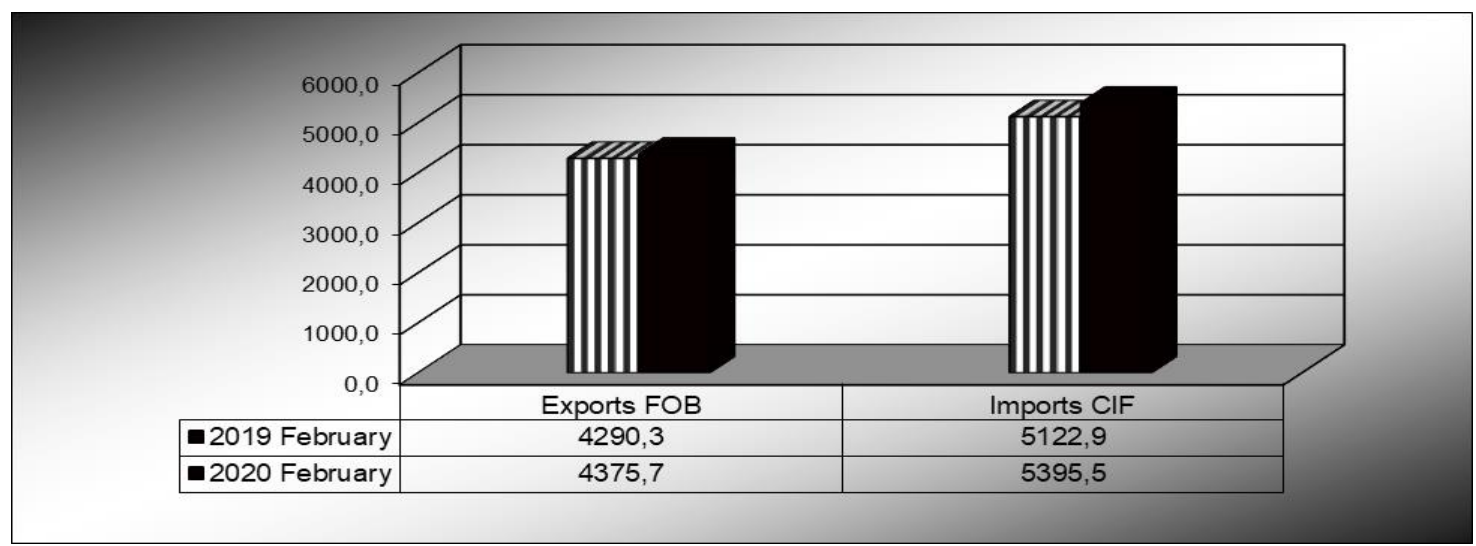

Figure 5. Comparative graphical representation for February 2019-2020 (expressed in millions of euros)

Source: National Institute of Statistics - International Trade in Goods of Romania

In February 2020, there was also an increase in both imports and exports, compared to 2019.

The increase is explained by the fact that the first case appeared at the end of the month we talked about, at that time we were not in a state of emergency, and the measures were to be taken the following month. This means that the impact on imports and exports hasn't been decisively influenced, so there hasn't been no decrease in the figures.

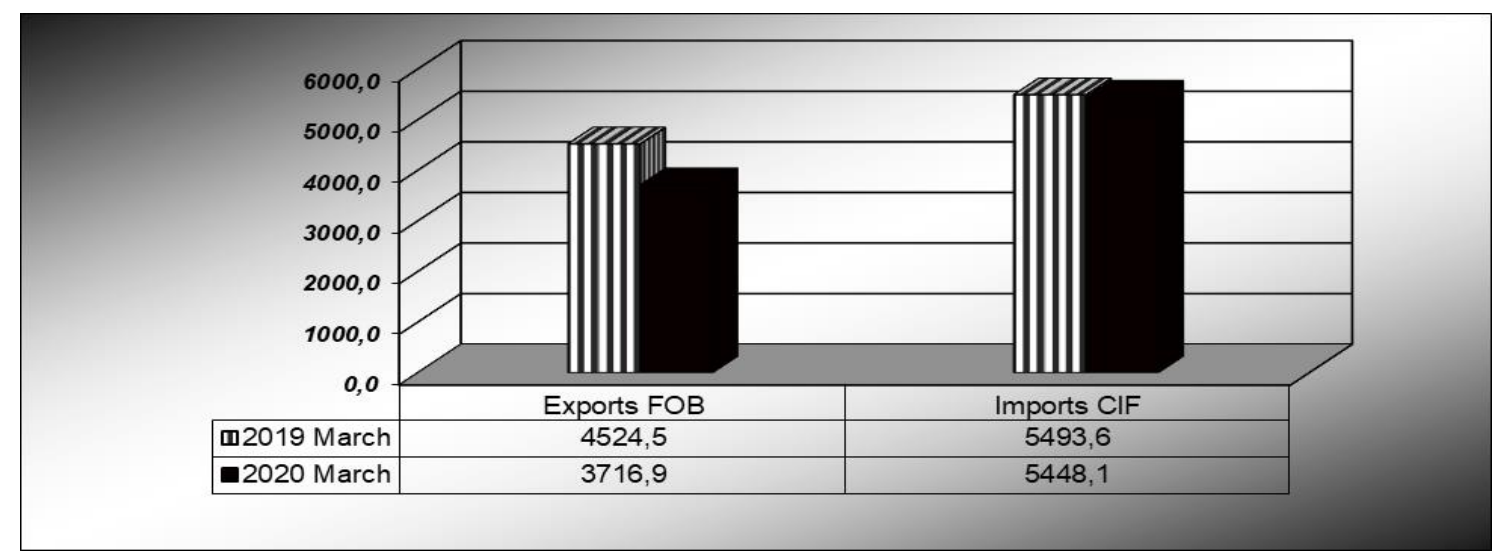

Figure 6. Comparative graphical representation of March 2019-2020

(expressed in millions of euros)

Source: National Institute of Statistics - International Trade in Goods of Romania

In the third month of the year, respectively March, we can see a negative difference comparing 2020 with 2019.

March 2020 was the month of change for Romania, it was the month in which many companies temporarily or permanently ceased their activity, which led to a decrease in exports of 897.6 million euros. The decrease of imports was much smaller, respectively 45.5 million euros, the explanation comes from the fact that the shipments of goods worked within the parameters.

According to data communicated by the National Institute of Statistics, in the first six months of 2020 , exports registered a decrease of $18.1 \%$ and imports registered a decrease of $12.6 \%$, compared to the same period in 2019.

Thus, Romania's trade deficit registered 8665 billion euros in the first half of 2020, and if we compare it with the first half of 2019, we see an increase of 935.7 million euros.

\subsection{Unemployment rate in Romania}

The unemployment rate was negatively influenced, due to the decrease in economic activity. The Romanian State, supported by the European Union, adopted political measures aimed at mitigating the impact on the labour market.

According to the predictions provided by the specialists, an increase of the unemployment rate is foreseen in the following years as well, the improvement being observed at the moment when the economy will be in an increasing trend (see Unemployment rate, 2020). 
In the following figure we graphically represented the unemployment rate in Romania during January and November 2020:

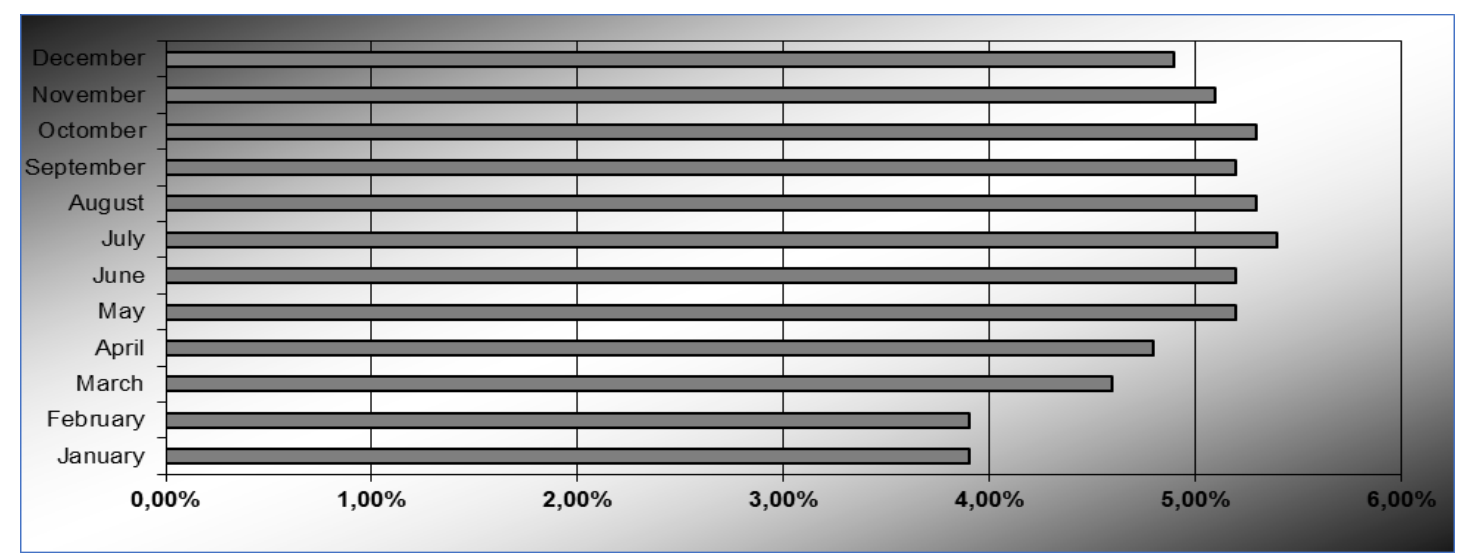

Figure 3. Graphical representation of the unemployment rate between January and November 2020 Source: National Institute of Statistics

In January and February of this year, the percentage of the unemployment rate remained constant, respectively 3.9\%. In March, the percentage increased to $4.6 \%$, which means a higher unemployment rate by $0.7 \%$, the main reason for the increase being the epidemic we are going through. Over the next few months, as we can see in Figure 3, we still had an increase but the percentage was not as high as in March, it fluctuated between $0.2-0.4 \%$.

The increase of $4.6 \%$ in March is mainly due to the companies that have been directly affected by the state decisions, a large part being Horeca employees.

In the third quarter of the previous year, the unemployment rate decreased compared to the second quarter, registering a percentage of 5.2\%. The highest percentage was registered among young people 15-24 aged and respectively a percentage of $19.2 \%$. Followed by the group of $25-34$ aged, with a $6.4 \%$ percentage.

\section{Conclusions}

Although the health crisis in 2020 does not seem to be as strong as that of 2008 , we should not wait for the return to the normal we were used to, because a crisis of this type is indefinite and can change its conditions from one day to the next. So that the businesses that exist at this time or the business to be developed in the market, must not be based on the habits created during this transit period, because the times are changing, the world moving in a new direction and the habits of the population in turn are constantly changed, which means that it is critical necessary for business to be based on an internal balance , to be open to change, to establish a flexible risk policy, so they will maintain their stability in times of economic and financial unpredictability.

Another conclusion from the current situation would be that the Romanian State should prepare concretely for risk situations, have concrete plans, special financial resources for such crisis situations and rethink its entire process, including also those factors, such as the medical system, essential in this case, unprepared in its turn in such a situation. The state should represent the support of the country, to offer alternatives and proposals that make the situations more efficient and at the same time minimize the negative repercussions.

Private companies, severely affected at the moment, should focus their resources and attention on the company's objective, so that in a situation like this, they prioritize their sustainable activities and minimize the attention dedicated to less sustainable activities during the crisis. Their premise being the added value they bring to the company and customers.

Change represents an opportunity for those open to understand and exploit it at full capacity, even if it is a sudden change as it was in the case of the pandemic, the activity must continue in the direction in which we notice sustainability, without forgetting that the priority in these periods is to produce, and to bring value to the company, last but not least to realize profit that covers our expenses, so the company will be able to get over the risk moment and to exploit to the maximum the newly discovered opportunities resulting in a company that runs effective and efficient even in the worst case scenario.

\section{References}

1. Simona, M. P. (2020), Opportunities for Romania from the perspective of the international context generated by the Covid-19 Crisis, Mai 2020 .

2. Minculete, G., \& Olar, P. (2016). "Push" snd "Pull" Systems in Supply Chain Management. Correlative Approaches in the Military Field. Journal of Defense Resources Management, 7(2).

3. Minculete, G., \& Chisega-Negrilă, M. (2014). Marketing management relational approaches focused on consumer's and customer's needs and desires. Economia. Seria Management, 17(2), 325-346. 
4. Minculete, G. (2013, May). Issues regarding electronic commerce and e-marketing. In International Scientific Conference" Strategies XXI" (Vol. 2, p. 26). " Carol I" National Defence University.

5. ${ }^{* * *}$ The Coronavirus is going to accelerate the post 2009 Crisis (2020), https://www.actvism.org/wp-content/uploads/2020/03/YanisVaroufakis_-_The-Coronavirus-is-going-to-accelerate-the-post-2008-Crisis_.pdf, accessed on December 2020.

6. ${ }^{* * *} B N R$ : interest rate (2020), https://financialintelligence.ro/bnr-diferentialul-ratelor-dobanzilor-de-pe-piata-financiara-a-contribuitla-stabilitatea-relativa-a-cursului-de-schimb-al-leului-in-conditiile-unei-scaderi-treptate-a-acestuia-inclusiv-in-pri/, accessed on December 2020.

7. $\quad{ }^{* * *}$ PIB Evolution (2020), https://insse.ro/cms/ro/tags/comunicat-evolutia-pib, accessed on December 2020

8. $\quad{ }^{* * *}$ Unemployment rate (2020), https://insse.ro/cms/ro/tags/comunicat-somaj-bim, accessed on December 2020.

9. ${ }^{* * *}$ Timeline - Council actions on Covid-19 (2020),

https://www.consilium.europa.eu/ro/policies/coronavirus/timeline/, accessed on January 2021.

10. ${ }^{* * * *}$ Exchange rate (2020), https://www.cursbnr.ro// accessed on January 2021.

11. ${ }^{* * * *} J o b s$ and economy during Coronavirus pandemic (2020), https://ec.europa.eu/info/live-work-travel-eu/coronavirus-response/jobsand-economy-during-coronavirus-pandemic_ro, accessed on January 2021. 